There is evidence that not only alpha but beta, gama and omega gliadins induce the mucosal changes of coeliac disease. There is also evidence that intreated coeliacs have high antibody titres to all these gliadins. We have used mouse T-cell lines to investigate the immunological cross-reactivity between these gliadins. Gluter-free Balb $\mathrm{c}$ mice were immunised with either alpha, beta, gamma or onega gliadin. Lymphocytes, isolated from the draining nodes, were cultured through three complete stimulation and rest cycles using the corresponding gliadins for stimulation. The specifically sensitised cell lines were tested in a stimulation assay against the other gliadins. The results show same cross-reactivity in all cases. Alpha-sensitive cell lines were most restricted, responding principally to alpha gliadin; omega cells responded equally to all gliadins. Conversely, alpha gliadin was the most effective stimulus across cell lines: amega was the least, stimulating principally onega cell lines.

We conclude that alpha gliadin is the most antigenic of the gliadins to these murine T-cells, presumably carrying the most determinants. However, the considerable cross-reactivity supports the belief that the immunological reaction in coeliac disease is against deteminant(s) present in all the gliadins.

ORGAN CULTLRE OF FOETAL RAT SMALL INTESTINE FOR TESTING QLUTEN 48 TOXICITY - A REAPPRAISA P. D. HOWDLE, G. M. WOOD, M. S. LOSOWSKY

Dept. of Medicine, St. James's University Hospital, Leeds, U.K.

Recent reports' of the use of organ culture of animal foetal small intestine to detect cereal toxicity have proposed its use for screening the toxicity of cereal peptides for coeliac mucosa. Some authors have assessed toxicity using morphological means, others by more objective biochenical means; the results have been variable. We have used foetal rat small intestine organ cultures to test the toxicity of gluten fraction III (GFIII), assessing the effect by morphological and biochenical means.

Small intestinal segments from 18-day old rat foetuses were used and were obtained from several foetuses in one litter for each experiment. They were cultured with and without GFIII for 48 hours. Segments before and after culture were observed histologically and significantly more developed definite tall villi after culture in the absence of GFIII $(p=0.009)$, associated with significantly less stratification $(p=0.014)$ and more columnar epithelial cells $(p=0.024)$. Alkal ine phosphatase activity fell during culture, whereas
$\alpha-g l u c o s i d a s e$
activity increased but there was no difference whether \& $\mathrm{FIII}$ was present or not.

Gluten toxicity for foetal rat intestine was detected using morphological, but not biochemical, means. Morphological assessment was difficult however, due to considerable variability within sections. We do not consider this type of culture to be sufficiently reliable for routine investigation of cereal toxicity, and advise caution in the interpretation of the results.

CLONING AND EXPRESSION OF A COLONOCYTE-SPECIFIC FIMBRTAL ADHESIN FROM AN ESCHERICHIA COLI STRAIN ISOLATED

49 FROM AN INFANT WITH SEVERE DYSENTERY-LIKE DIARRHOEA. G.T.Hinson, S.Knutton, P.H.Williams and A.S.McNeish. Department of Genetics, University of Leicester, Leicester, LEI 7RH and Institute of Child Health, University of Birmingham, Bl6 8ET, U.K.

E.coli strain 469-3 (021:NM) expresses mannose-resistant haemagglutination (MRHA) of human erythrocytes, adheres to cultured human epithelial ( $\mathrm{HEP}-2)$ cells and to the brush border of human colonic (but not duodenal) enterocytes. The adhesin, an aggregate of a 14 kilodalton protein subunit, has now been identified by electron microscopy and consists of fine $\sim 2-\mathrm{nm}$ diameter fibrils. The chromosomally located genetic deteminants of the adhesin were isolated by cosmid cloning and expressed in E.coli $\mathrm{Kl} 2$. Several recombinant cosmids expressing a MRHA phenotype were identified and 1 such clone was used to subclone smaller DNA fragments able to confer the same MRHA and adherence properties as the parent strain. A 16.4 kilobase chromosomal DNA fragment cloned in pBR322 (pGTHI) expressed MRHA of human erythrocytes, adhered to HEp-2 cells and to human colonocyte brush borders. The identity of the cloned adhesin was confimed by biochemical, genetic, electron microscopical and immunological comparison with the adhesin synthesized by 469-3. tion and a VIP-ergic innervation of the tion and a VIP-ergic innervation of the epithelial layer has been demonstrated, we investigated binding, internalization and degredation of VIP by pig jejunum epithelial cells. Enterocytes were isolated by a non-enzymatic dissociation procedure. 125 I-VIP binding was time- and temperature dependent and was inhibited dose-dependently by $V I P\left(K_{D}=1.5 \pm 0.2 \mathrm{nM}\right.$, mean $\left.\pm S D ; n=5\right)$ and secretin (half maximal binding $10 \mu M$ ) but not by other peptides. Internalized radioactivity was separated from cell surface-bound radioactivity by washing the cells with isotonic saline, $\mathrm{pH} 2.5$. At $37^{\circ} \mathrm{C}$ the amount of internalizeq radioactivity increased till $30 \mathrm{~min}$ and represented $30 \%$ of cell bound radioactivity. At $10^{\circ} \mathrm{C}$, all radioactivity bound to the celis was acid dissociable. To investigate degredation of VIP, cells were incubated with VIP $(5-20 \mathrm{nmol} / 1)$ and the reaction mixture was analysed by HPLC and metabolites were identified by amino acid analysis. After only $30 \mathrm{sec}$ incubation, des(His)VIP (fragment 2-28) was identified as a major metabolite, representing $30 \%$ of the substrate In conclusion normal enterocytes internalized VIP but, in view of the rapid cell-surface degradation, it is suggested that VIP is not internalized as intact peptide.As VIP $(2-28)$ has only $1 \%$ of the bio logical activity of VIP, its action in the gut may be terminated
py aminopeptidases.

\title{
51 CHIIDREN
}

M-R Ståhlberg, E Hietanen, and M Mäki

Departments of Paediatrics and Physiology, University of Turku, and Department of Paediatrics, University Tampere, Finland

Liver is the main organ of detoxication. However, detoxication enzymes are present in the intestinal mucosa. We studied the activities of these enzymes in relation to mucosal structure.

Activities of different detoxication enzymes were measured | 1 n 194 samples of peroral small intestinal capsule biopsies from children in whom the biopsies were taken as a part of gastrointestinal investigations for various reasons. Alkaline phosphatase was used as reference and its activity was $161 \pm 9,118 \pm 17$, and $61 \pm 10$ $\mathrm{nmol} / \mathrm{min} / \mathrm{mg}$ protein in samples with normal mucosa, partial villous atrophy, and total villous atrophy, respectively. Aryl hydrocarbon hydroxylase and ethoxycoumarin o-deethylase activities did not vary in relation to mucosal structure. On the contrary, glutathione peroxidase activity was significantly decreased in villous atrophy: $27.3 \pm 2.1,21.4 \pm 4.0$, and $4.8 \pm 1.6 \mathrm{pmol} / \mathrm{min} / \mathrm{mg}$ protein in normal, partially atrophied, and severely atrophied samoles, respectively. Also epoxide hydrolase was diminished in relation to mucosal structure: $43.6 \pm 2.0,39.2 \pm 4.0$, and $26.3 \pm 4.5 \mathrm{pmol} / \mathrm{min} / \mathrm{mg}$ protein in the same order as above.

Changes in villous structure alter mucosal capacity to detoxify ingested foreign compounds and potentially toxic products of metabolism.

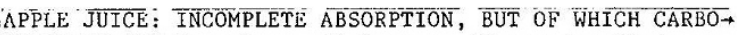

52 HYDRATE? CMF Kneepkens, AC Douwes, JM van der Klei-van Moorse1, C Jakobs. Department of Paediatrics, Fre University Hospital, Amsterdam, The Netherlands.

Apple juice (AJ) is a popular drink in toddlers. Due to the wideispread belief that it has an anti-diarrhoeal effect, it frequently is advocated in case of chronic diarrhoea. Recently, however, it has been suggested that AJ promotes diarrhoea in toddlers either due to fructose (F) or to sorbitol (S). AJ contains about $60 \mathrm{~g} / 1$ of $\mathrm{F}, 20 \mathrm{~g} / 1$ of glucose, and possibly up to $10 \mathrm{~g} / \mathrm{l}$ of $\mathrm{S}$. Aim of this study was to investigate the incidence of incomplete absorption of AJ carbohydrates and to identify the responsible carbohydrate, using breath hydrogen (BH) tests. Methods. We studied 10 children, 7 without and 3 with chronic nonspecific diarrhoea (CNSD), all AJ consumers, ages $1-4 \frac{1}{2} \mathrm{y}$. BH tests were done with $150-250 \mathrm{ml}$ of $\mathrm{AJ}$. In 7 (2 CNSD), tests were repeated with F (10g); in $4 / 7$ (1 CNSD) also with $S(5 \mathrm{~g})$. BH increase $>10 \mathrm{ppm}$ indicated positive (+ve) tests. Results. AJ tests were tve in $5 / 7$ controls $(20-55 \mathrm{ppm})$ and in all 3 CNSD patients (42-69ppm). In addition, $2 / 5$ controls and $2 / 2$ CNSD patients had +ve $\mathrm{F}$ tests $(16-55 \mathrm{ppm})$. The 3 controls with negative $\mathrm{F}$ tests had +ve $\mathrm{S}$ tests $(16-29 \mathrm{ppm})$; one CNSD patient had a negative $\mathrm{S}$ test. Actual $\mathrm{S}$ content of A.J (assessed by GLC) was $4.3 \mathrm{~g} / 1$ In the CNSD patients, stools became normal after AJ elimination. Conclusions. These results indicate that $\mathrm{AJ}$ absorption frequently is incomplete in toddlers and may result in CNSD, and that. neither $F$ nor $S$ can be held solely responsible for this phenomenon. 